\title{
Temperature and Shear Rate Affecting the Viscosity and Secondary Structural Changes of Soy $11 S$ Globulin Measured by a Cone-Plate Viscometer and Fourier Transform Infrared Spectroscopy
}

\author{
Rong-Huei. Chen, Yi-Chang Ker and Ching-Shyong WU \\ Department of Marine Food Science, National Taiwan Ocean University, \\ Keelung 20224, Taiwan, R.O.C.
}

Received October 24, 1989

\begin{abstract}
The effects of temperature, shear rate, shear time, and concentration on the rheological properties of $11 \mathrm{~S}$ globulin in ionic strength $0.5, \mathrm{pH} 7.6$ phosphate buffer were studied by a cone and plate viscometer at shear rates up to $384 \mathrm{sec}^{-1}$. The secondary structure changes caused by elevated temperature and shearing were also monitored by Fourier transform infrared spectroscopy (FTIR). The effects of concentration on apparent viscosity were pronounced. A 3-percent solution behaved as a Newtonian solution. The solutions become pseudoplastic when the concentrations were higher than $5 \%$. The effects of shearing time up-to $30 \mathrm{~min}$ on apparent viscosity also depended on the concentration. Shear thinning first become nearly time-independent, later was observed in 5 or $10 \%$ solution, while $3 \%$ and $20 \%$ solutions behaved as time independent. Increasing temperature at $1.4 \mathrm{C} / \mathrm{min}$ with shearing time up to $40 \mathrm{~min}$ result in the 3,5 , and $10 \%$ solutions behaving with shear thinning earlier and with shear thickening later. The reason that elevation temperature and longer shear time caused shear thickening in the solution was a change of secondary structure seen in the FTIR spectrum. The amount of $\alpha$-helix of $11 \mathrm{~S}$ globulin increased from $7.8 \%$ to 19.6 or $28.1 \%$ as the temperature increased from $25^{\circ} \mathrm{C}$ to 80 or $90^{\circ} \mathrm{C}$, respectively.
\end{abstract}

Viscosity is an important functional property in fluid foods. The study of viscosity has practical significance in relation to process engineering, new product development, and quality control., ${ }^{1,2)}$ Molecular volume, mass, the distance between the molecules, and attractive forces between the molecules are factors affecting the viscosity. Therefore, changes in viscosity can be used to monitor the changes in physico-chemical interactions between proteins or conformational changes of component in solution or dispersion. ${ }^{3-4)}$ Soy proteins with their excellent functional properties have been used as an important ingredient in various food systems. Viscosity studies on soy proteins were mainly on extracted soy proteins, e.g., acid-precipitated protein, soy isolate, or concentrates. The effects of protein concentrate, ${ }^{5-7)}$ shearing time, ${ }^{5,8,9)}$ process, ${ }^{5,7)} \mathrm{NaCl}$ concentration, ${ }^{5,7,9,10)} \mathrm{pH}^{5,7,11)}$ sonication, ${ }^{6}$ ) and temperature, ${ }^{11}$ etc. on viscosity have been reported. However, few studies on soy
11S globulin have been done. Umeya et al. ${ }^{8)}$ studied th effects of ionic strength on the apparent viscosity of soy glycinin. Catsimpoolas and Meyer, ${ }^{12)}$ Ishino and Okamoto, ${ }^{13)}$ and Ishino and $\mathrm{Kudo}^{14)}$ investigated the changes of viscosity of sol/gels induced by heating or alcohol.

The objectives of this study are to elucidate the effects of concentation, shear time, shear rate, and temperature on the viscosity of soy $11 \mathrm{~S}$ globulin in ionic strength $0.5, \mathrm{pH} 7.6$ phosphate buffer and to study the effects of temperature and shearing on the secondary structure of soy $11 \mathrm{~S}$ globulin by FTIR.

\section{Materials and Methods}

Preparation of soybean $11 S$ globulin. Purified soybean $11 \mathrm{~S}$ globulin, prepared by selective thermal denaturation and solubility in a high ionic strength envelope, ${ }^{15)}$ was used as the raw material. The purity observed by gel 
Table I. Protein Concentration, Shear Rate, Shear Time, Temperature Increasing Program, and Temperature Used in Rheological Properties Studies of $11 \mathrm{~S}$ Globulin

\begin{tabular}{|c|c|c|c|c|}
\hline & $\begin{array}{l}\text { Shear dependency } \\
\text { study }^{a}\end{array}$ & $\begin{array}{c}\text { Time dependency } \\
\text { study }^{b}\end{array}$ & $\begin{array}{c}\text { Temperature increasing } \\
\text { and time dependency } \\
\text { study }{ }^{c}\end{array}$ & $\begin{array}{l}\text { Elevated temperature } \\
\text { and time dependency } \\
\text { study }\end{array}$ \\
\hline $\begin{array}{l}\text { Protein conc. } \\
\qquad \% \mathrm{w} / \mathrm{v})\end{array}$ & $\begin{array}{l}\text { Shear rate } \\
\left(\sec ^{-1}\right)\end{array}$ & $\begin{array}{l}\text { Shear time } \\
\text { (min) }\end{array}$ & $\begin{array}{l}\text { Temp. increasing } \\
\text { program }\left(25-80^{\circ} \mathrm{C}\right)\end{array}$ & $\begin{array}{l}\text { Temperature } \\
\left({ }^{\circ} \mathrm{C}\right)\end{array}$ \\
\hline 3 & $9.6-384$ & 30 & $1.4^{\circ} \mathrm{C} / \mathrm{min}$ & \\
\hline 5 & $9.6-384$ & 30 & $1.4^{\circ} \mathrm{C} / \mathrm{min}$ & 80,90 \\
\hline 10 & $9.6-384$ & 30 & $1.4^{\circ} \mathrm{C} / \mathrm{min}$ & $25,50,80,90$ \\
\hline 20 & & 30 & $1.4^{\circ} \mathrm{C} / \mathrm{min}$ & 80,90 \\
\hline
\end{tabular}

a Temperature was $25^{\circ} \mathrm{C}$ and the hysteresis loop was completed within 8 min.

$b$ Shear rate was $9.6-384 \mathrm{sec}^{-1}$ and temperature was $25^{\circ} \mathrm{C}$.

c Shear rate and shear time at this study were $384 \mathrm{sec}^{-1}$ and $30 \mathrm{~min}$, respectively.

¿ Same as $c$.

electrophoresis was greater than $95 \%$. It was stored in a desiccator until use.

Rheological properties. A Brookfield cone and plate viscometer (Brookfield, DV-II, U.S.A.) was used with a $2.4 \mathrm{~cm}$ diameter and $1.565^{\circ}$ angle cone spindle. The concentration of sample was adjusted to $3,5,10$, and $20 \%$ (from lyophilized $11 \mathrm{~S}$ globulin (weight) with ionic strength $0.5, \mathrm{pH} 7.6$ phosphate buffer (volume)). About $1 \mathrm{ml}$ of sample was carefully spread to cover all the plate surface. The distance between the cone and plate was also adjusted such that the cone apex just touched the surface of the plate. (Cone/plate temperature was controlled by a Firstek programmed isothermer (Firste, KB403, Taipei) (Accuracy $\pm 0.01^{\circ} \mathrm{C}$ ), while the cone/plate was sealed with a tape on the outside to avoid water vaporization during the experiment, which might cause error due to the change of concentration for those runs at temperatures higher than $50^{\circ} \mathrm{C}$ or the long running time of the time dependency study. The corresponding viscosity (or shear stress) was recorded by a recorder (Watanabe, SR6311, Japan) automatically. Table I lists the protein concentration, shear rate, shear time, temperature increasing program, and temperature used in the rheological properties studies of $11 \mathrm{~S}$ globulin in this experiment.

Fourier transform infrared (FTIR) analysis. A Boman DA3.002 FT-IR spectrometer (Boman, DA3.002, Canada) with a $\mathrm{Hg}-\mathrm{Cd}-\mathrm{Te}$ detector was used for the experiment. The spectral resolution is $2 \mathrm{~cm}^{-1}$. Fourier selfdeconvolution was done using the technique of Kauppinen et $a{ }^{16)}$ The $k$, a resolution enhancement of 2.4 and the $s$, the half width at half height of the chosen line shape function of $6.5 \mathrm{~cm}^{-1}$ were used. The $k$ value of 2.4 was justified from the $\log (S / N)$ of approximately larger than 500. After self-deconvolution and a second derivative of deconvolution, the original overlapped peaks can be sepa- rated, the second derivative of deconvolution peak position and its absorbance can then be picked and printed out using a peak picking program (interval spectra was $1.0 \mathrm{~cm}^{-1}$ and tolerance was 1.0 ), which was used to calculate the quantity of secondary structure of the protein.

The spectra of the sheared $11 \mathrm{~S}$ globulin under different heating temperatures of $25,50,80$, and $90^{\circ} \mathrm{C}$ were obtained by the following procedure: the sample was cooled down to room temperature immediately after the shearing and thermal treatment. The shearing and thermal treatments were restricted to a shear rate of $384 \mathrm{sec}^{-1}$ and heating times and temperatures of $30 \mathrm{~min}$ at $50^{\circ} \mathrm{C}, 16 \mathrm{~min}$ at $80^{\circ} \mathrm{C}$, and $8 \mathrm{~min}$ at $90^{\circ} \mathrm{C}$, due to the limitation of the viscometer of $64 \mathrm{cPs}$. The samples were collected and then lyophilized and made into $\mathrm{KBr}$ pellets by mixing the lyophilized $11 \mathrm{~S}$ globulin $(2 \mathrm{mg})$ with $\mathrm{KBr}(10 \mathrm{mg})$ and pressing to form the pellet. The pellet was placed in the sample cell and scanning 200 times.

\section{Results and Discussion}

\section{Effects of shear rate on apparent viscosity of IIS globulin}

Figure 1 shows the relationships between shear rate and shear stress and the hysteresis curves resulted of soybean $11 \mathrm{~S}$ globulin at 3,5 , and $10 \%$ in ionic strength 0.5 , pH 7.6 phosphate buffer. The flow behavior index (n) and fluid consistency index (b) $\left(\mathrm{dyn} \cdot \mathrm{s} / \mathrm{cm}^{2}\right) \mathrm{calcu}$ lated from the power law equation were 0.68 (n), $4.4(\mathrm{~b})$, and $0.50(\mathrm{n}), 2.4$ (b) for $5 \%$ and $10 \%$ respectively. The flow behavior index (n) was less than one and caused a hysteresis loop 
indicated the fluids have pseudoplastic flow, which means either a continuous breakdown or realignment of the molecules of $11 \mathrm{~S}$ globulin along the streamline of flow or both, thus there was less resistance to flow while the shear

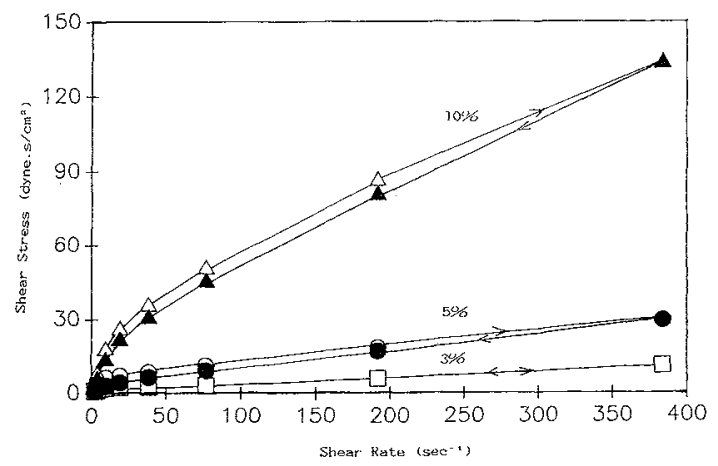

Fig. 1. Effects of Shear Rate on Shear Stress of 3,5 and $10 \% 11 \mathrm{~S}$ Globulin Solutions at $25^{\circ} \mathrm{C}$, and on the Hysteresis Behavior. rate was increasing. ${ }^{17)}$ However, the $3 \%$ solution was shear-independent and had Newtonian flow. The results indicated that the effect of concentration on apparent viscosity was pronounced. The $3 \%$ solution behaved as a Newtonian solution and became pseudoplastic when the concentration was higher than $5 \%$.

Effects of shearing time on apparent viscosity of 11S globulin

The relationship between apparent viscosity and shearing time from 0 to $30 \mathrm{~min}$ of $3 \%$ and $20 \%, 5 \%$, and $10 \%$ solutions at $25 \%$ and a shear rate 9.6 to $384 \mathrm{sec}^{-1}$ is shown in Figs. 2, 3 , and 4 , respectively. For $3 \%$ IIS globulin, the apparent viscosity remained constant during the entire shearing period from 9.6 to $384 \mathrm{sec}^{-1}$. The fluid was time-independent

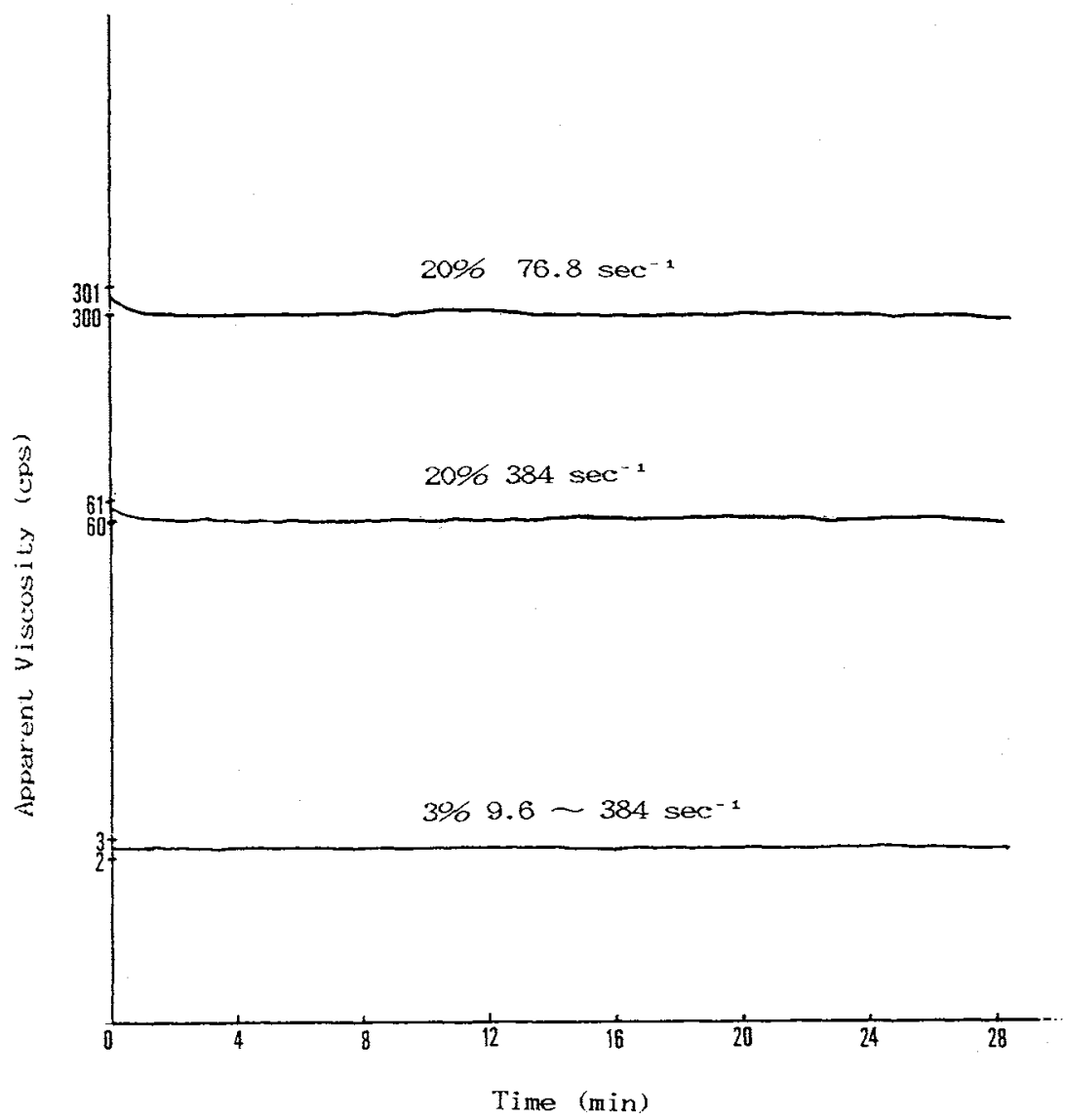

Fig. 2. Effects of Shearing Time on the Apparent Viscosity of 3\% 11S Giobulin Solution at a Shear Rate of $9.6-384 \mathrm{sec}^{-1}$ and $25^{\circ} \mathrm{C}$, and of $20 \% 11 \mathrm{~S}$ Globulin at a Shear Rate of $76.8,384 \mathrm{sec}^{-1}$ and $25^{\circ} \mathrm{C}$. 


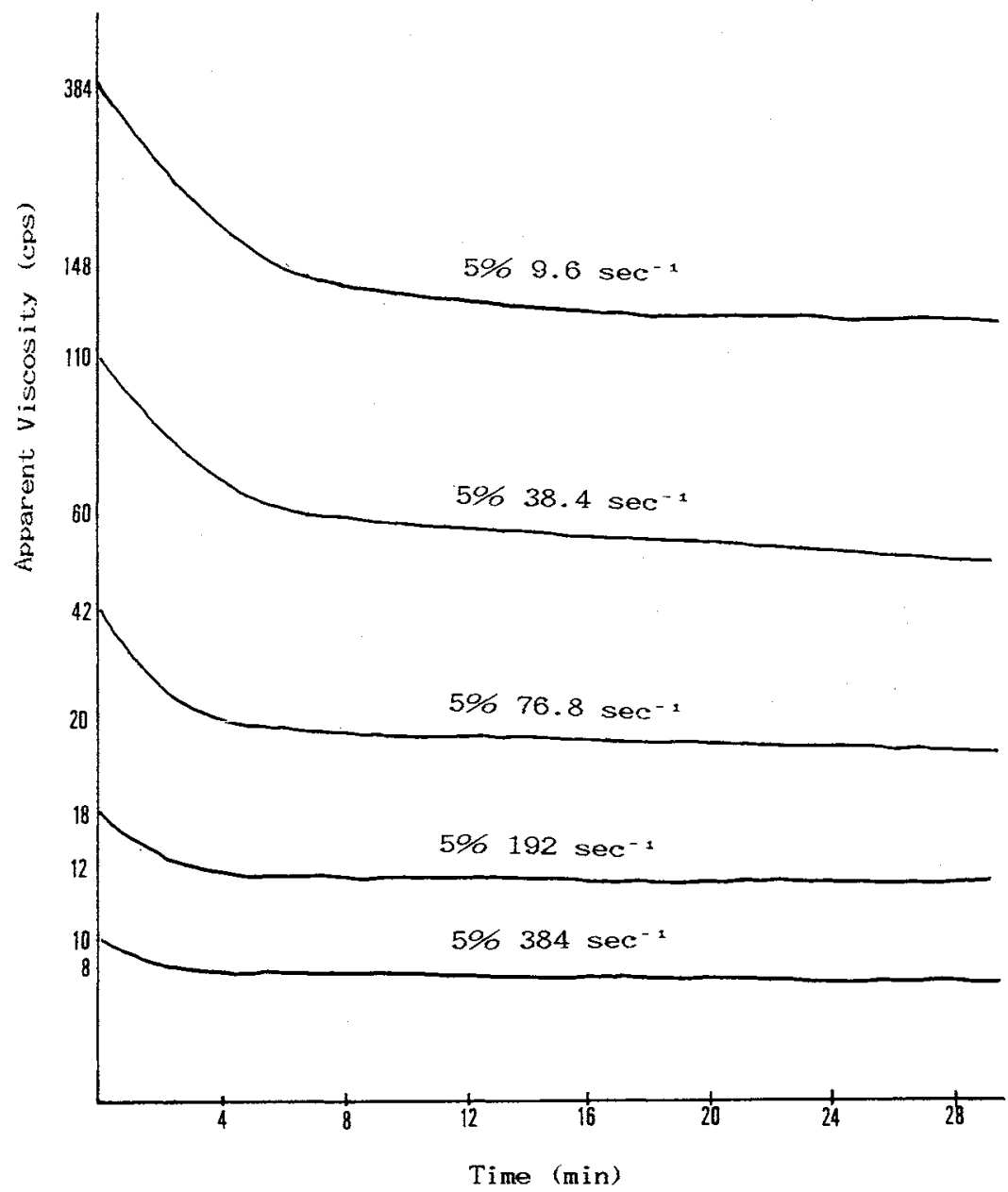

Fig. 3. Effects of Shearing Time on the Apparent Viscosity of 5\% 11S Globulin Solution at a Shear Rate of $9.6-384 \mathrm{sec}^{-1}$ and $25^{\circ} \mathrm{C}$.

during the whole shearing period of $30 \mathrm{~min}$ as a Newtonian fluid at such low concentrations. For the $20 \%$ solution, shear thinning occurred in a very short time,' less than 1 and $1.5 \mathrm{~min}$ for $384 \mathrm{sec}^{-1}$ and $76.8 \mathrm{sec}^{-1}$ shear rate respectively, then remained constant during the rest of the shear period. The cause for shear thinning at the beginning was that the particle size distribution was large and the associated particles had to break apart to a uniform dispersion right after the start of shearing thus decreasing the apparent viscosity. The time-independence may due to hydration of $11 \mathrm{~S}$ globulin making system too concentrated to flow freely and rendering the apparent viscosity constant, as shown in
Fig. 2.

The $5 \%$ and $10 \%$ solutions showed similar flow behavior such as 1) Shear thinning at the beginning of shearing, comparing the same concentration solutions. 2) The lower the shear rate, the larger the apparent viscosity difference was observed. The apparent viscosity difference was the difference between the beginning and at the time of equilibrium apparent viscosity (EAV), which is a hydrodynamic equilibrium state. 3) The lower the shear rate, the longer the shearing time needed to reach the EAV at the same shearing rate. 4) The higher the concentration, the longer the shearing time needed to reach the EAV. 5) The higher the concentration, the higher the ap- 


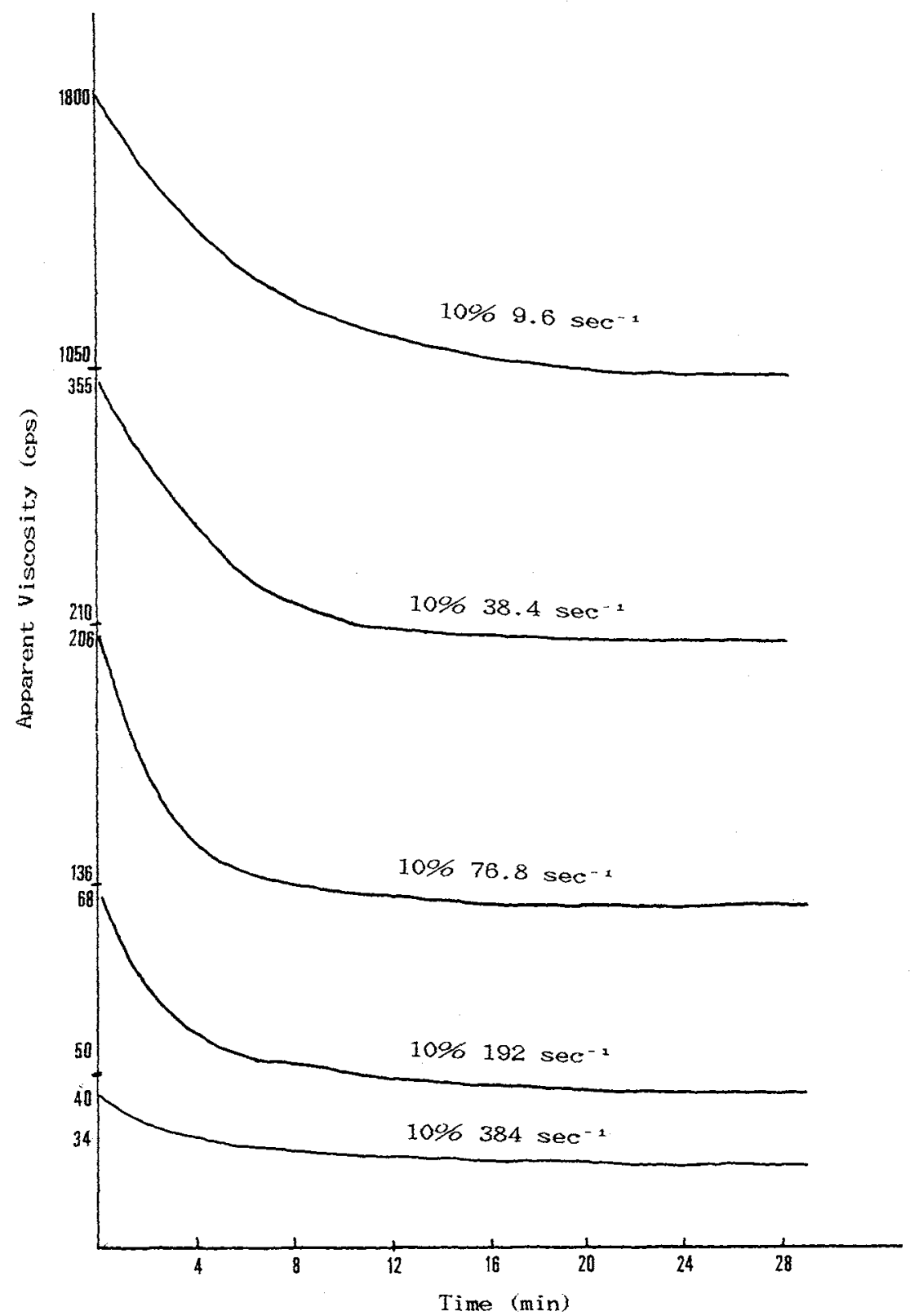

Fig. 4. Effects of Shearing Time on the Apparent Viscosity of $10 \% 11$ S Globulin Solution at a Shear Rate of $9.6-384 \mathrm{sec}^{-1}$ and $25^{\circ} \mathrm{C}$.

parent viscosity difference was observed. Hermansson ${ }^{5}$ reported that the dispersion of promine-D $(12 \%)$ was thixotropic; there was no difference between the flow curve before and after shearing and resetting was observed. This indicated that the structure of promine-D, broken down during shearing, was reversibly reformed. But Pradipasena and $\mathrm{Rha}^{18)}$ re- ported that the relationship between viscosity and shearing time of $\beta$-lactoglobulin at protein concentrations of $10-30 \%$, at a shear rate of 6856-17140 $\mathrm{sec}^{-1}$, showed rheopectic properties. The rheopectic properties were explained by the fact that in shearing, protein molecules could be unfolded or uncoiled, thus changing or increasing the shape, size, and effective 


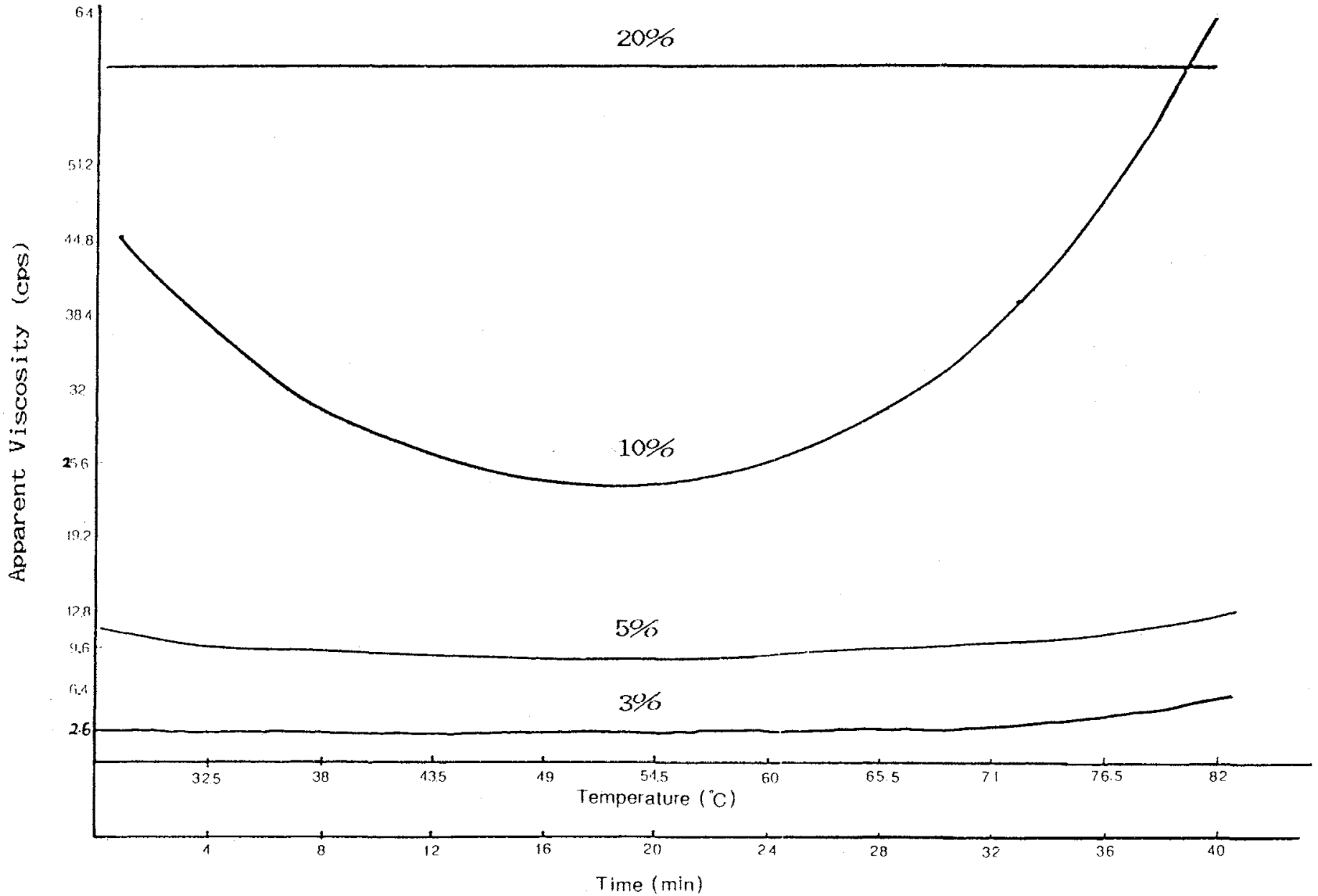

Fig. 5. Effects of Shearing Time and Heating from $25^{\circ} \mathrm{C}$ at $\left(1.4^{\circ} \mathrm{C} / \mathrm{min}\right)$ to $85^{\circ} \mathrm{C}$ on Apparent Viscosity of 3 , 5,10 , and $20 \%$ IIS Globulin Solutions at a Shear Rate of $384 \mathrm{sec}^{-1}$. 
volume of the solute in solution. However, in this study, the fluid showed shear-thinning at the beginning of shearing. It can be explained because under shearing the hydrodynamic forces were large enough to break apart the linking force that originally maintained the associated molecules or particles. The reduction in size of the associated structural units by hydrodynamic force corresponds to a smaller resistance unit against the flow, thus decreasing the apparent viscosity with time. ${ }^{19)}$ In addition, the lower the shear rate, the smaller the shear energy to be dissipated. In other words, the magnitude of breaking the associated particles apart was small, therefore it needed a longer time to break apart the associated particles that is, it needed a longer time to reach the EAV state. Assuming the extent of hydrodynamic force was nearly equal to breaking apart the associated particles, the lower the shear rate, the larger the EAV was observed; the higher the concentration, the larger the numbers of linking forces, therefore it need more time to break apart or to reach the EAV, and a relative high apparent viscosity difference. The reasons for the timeindependent flow properties after the shear thinning period may be inferred as (1) the soybean $11 \mathrm{~S}$ globulin was more compact and stable, higher molecular weight molecule than $\beta$-lactoglobulin, (2) the shear rate and temperature used in this experiment were too low to cause any conformational change of $11 \mathrm{~S}$ globulin, and (3) the equilibrium hydrodynamics state was obtained. ${ }^{3)}$

\section{Effects of shearing time and temperature on apparent viscosity}

Figure 5 shows the changes of apparent viscosity of $11 \mathrm{~S}$ globulin with shearing time and temperature. The increasing in temperature was controlled by a constant heating rate of $1.4^{\circ} \mathrm{C} / \mathrm{min}$ up to $85^{\circ} \mathrm{C}$. For the $3 \%$ solution, the apparent viscosity didn't change during the first $30 \mathrm{~min}$ of shearing or temperature up to $70^{\circ} \mathrm{C}$, then increased with the increase of temperature and shearing time although at a small magnitude. The increase may be attributed to the change of $11 \mathrm{~S}$ globulin due to the syneresis effects of hydration, shearing, and higher temperature, which induced the unfolding of $11 \mathrm{~S}$ globulin or increased its axial ratio. ${ }^{15.20)}$ For the $10 \%$ solution, before $20 \mathrm{~min}$ or before the solution temperature reached $54.5^{\circ} \mathrm{C}$, the apparent viscosity decreased with shearing time. The decrease in the apparent viscosity may due to: 1) the solvent viscosity decreasing with the increased temperature, 2) the tendency of $11 \mathrm{~S}$ globulins to align themselves along the streamlines of flow with shearing time that resulting in a reduced shear stress with shearing time, or 3 ) the shearing force was large enough to break apart the associated molecules or particles resulting in a smaller resistance unit against the flow. However, after $20 \mathrm{~min}$ or after the solution temperature went above $54.5^{\circ} \mathrm{C}$, the apparent viscosity significantly increased along with the elevation of temperature up to $82^{\circ} \mathrm{C}$. The reasons for this significant increase were thought to be the syneresis effects described above plus the molecule entanglement factor, the interaction of shearing, high temperature, and concentration increasing the effective volume of $11 \mathrm{~S}$ globulin to a point above the coil overlap concentration. ${ }^{21)}$ The $5 \%$ solution showed trends similar to the $10 \%$ solution but different in magnitude in the decrease or increase in the apparent viscosity, and different in the shearing time at which the shear thinning changed to shear thickening. The difference may due to the difference in effective volume in solution. However, for the $20 \%$ solution, the apparent viscosity was independent of shearing time and temperature. It might due to aggregates formed from highly concentrated swelled molecules at $25^{\circ} \mathrm{C}$ and later gel formed by the thermal activation of the protein sol to a gel as the temperature increased; the shear stress applied at this shear rate had no effect upon the system.

The apparent viscosity changes with increasing temperature and shearing time were most pronounced for the $10 \%$ solution among those shown in Fig. 5. Therefore $10 \% 11 \mathrm{~S}$ globulin was further studied at constant temperatures of $25^{\circ} \mathrm{C}, 50^{\circ} \mathrm{C}, 80^{\circ} \mathrm{C}$, and $90^{\circ} \mathrm{C}$, shown in Fig. 


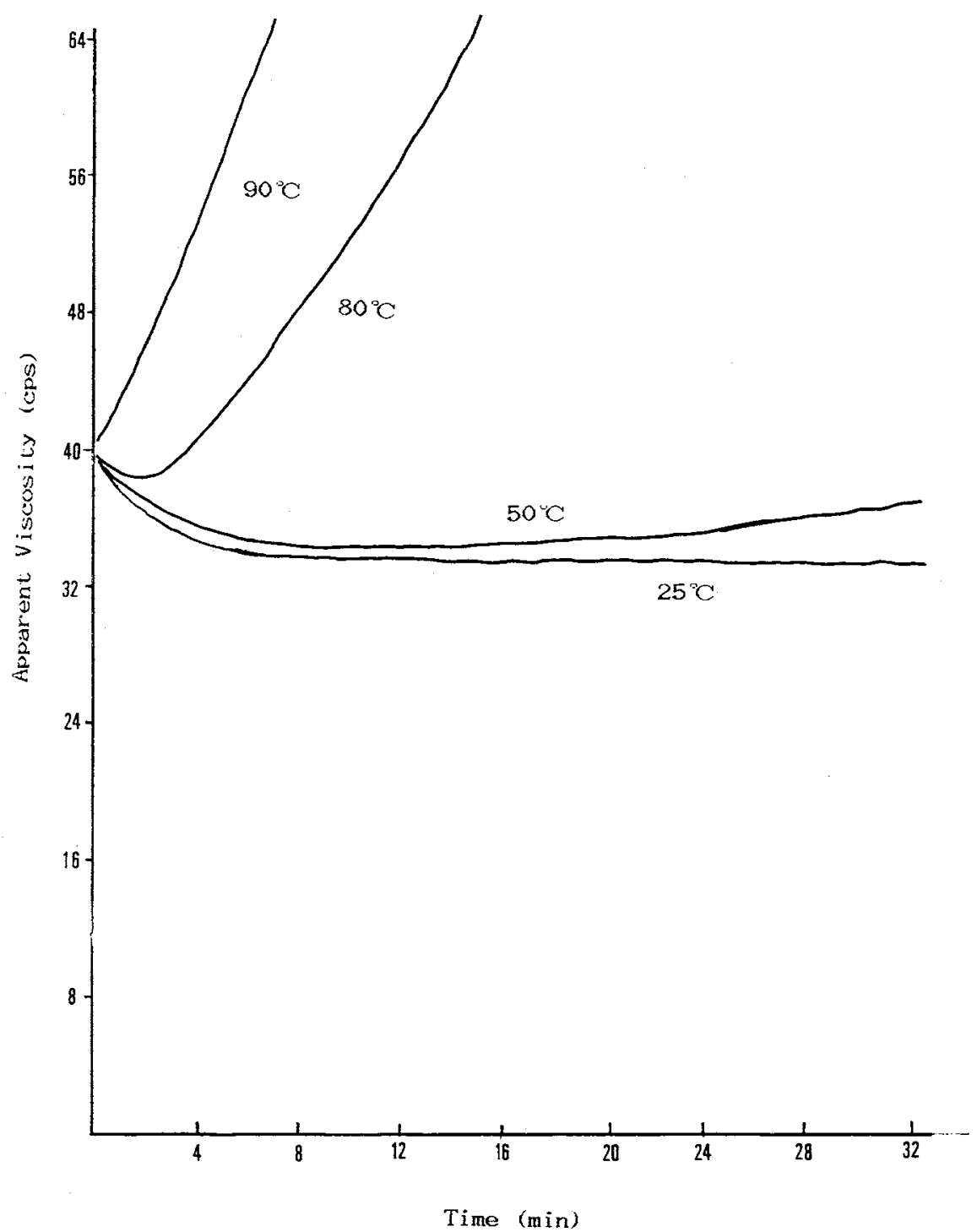

Fig. 6. Effects of Shearing Time and Temperatures on the Apparent Viscosity of $10 \% 11$ S Globulin Solution at a Shear Rate of $384 \mathrm{sec}^{-1}$.

6. At $25^{\circ} \mathrm{C}$, it was shear thinning during the first $4 \mathrm{~min}$ of shearing, then the change remained constant. At $50^{\circ} \mathrm{C}$, the $11 \mathrm{~S}$ globulin showed shear thinning during the first $8 \mathrm{~min}$ of shearing. After that, nevertheless, the increase in apparent viscosity as the shearing time increased was within $3 \mathrm{cPs}$. However, at $80^{\circ} \mathrm{C}$ and $90^{\circ} \mathrm{C}$, the time to reach the limit of this viscometer, $64 \mathrm{cPs}$, was 16 and $8 \mathrm{~min}$, respectively. The reasons for the sharp increase of apparent viscosity were the same as described above.

Since the apparent viscosity of the $10 \%$ solution increased sharply at temperatures higher than $80^{\circ} \mathrm{C}$, the apparent viscosity of $5 \%$ and $20 \%$ solutions at temperatures higher than $80^{\circ} \mathrm{C}$ and a shear rate of $384 \mathrm{sec}^{-1}$ were studied for comparison. For the $5 \%$ solution, the way the apparent viscosity decreased and then increased was similar to the $10 \%$ solution. The reflection time occurred around $3 \mathrm{~min}$ and $1.5 \mathrm{~min}$ for 80 and $90^{\circ} \mathrm{C}$, respectively, 

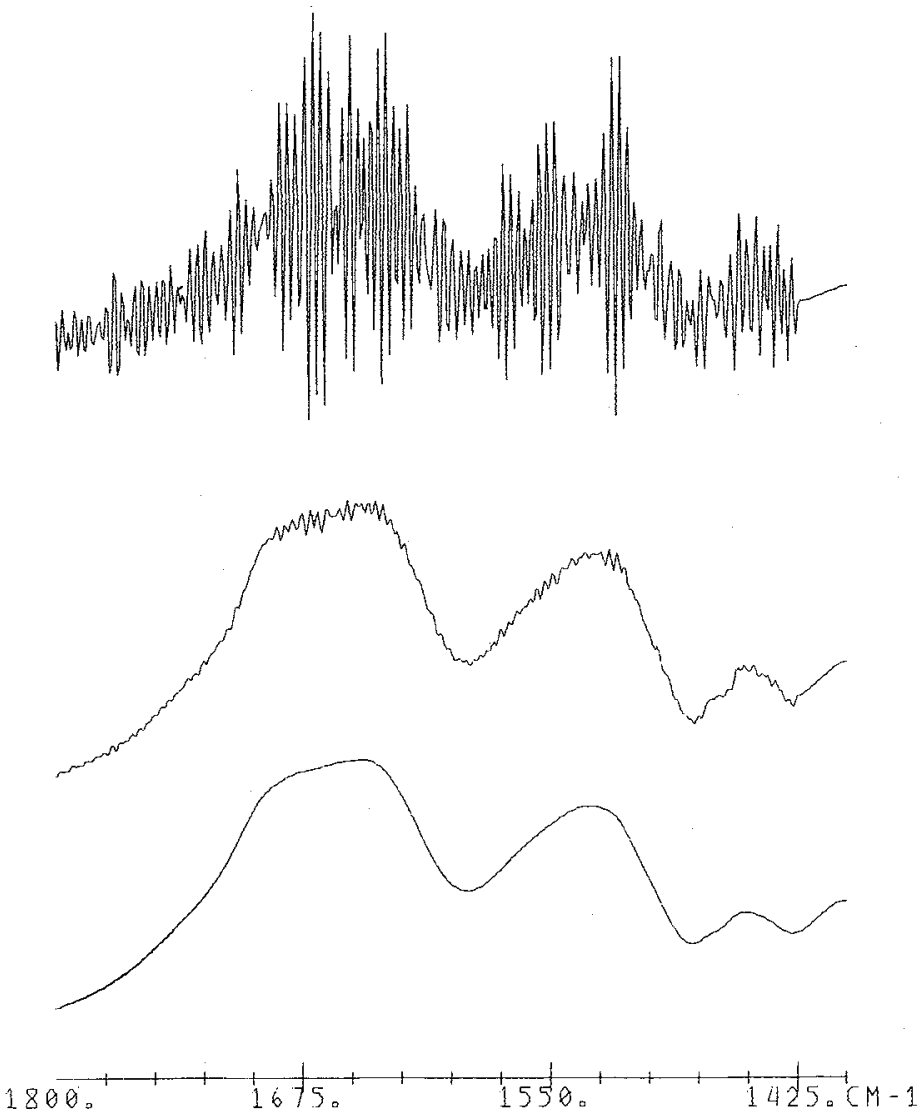

Fig. 7. The Amide I and Amide II Spectra of Sheared $11 \mathrm{~S} \mathrm{Globulin}$ at a Shear Rate of $384 \mathrm{sec}^{-1}$ and $25^{\circ} \mathrm{C}$, Undeconvoluted Spectra (Bottom), Deconvoluted Spectra (Middle), and Second Derivative of Deconvoluted Spectra (top).

( $k=2.4$ and $s=6.5 \mathrm{~cm}^{-1}$ were used for the deconvolution.)

compared to $2 \mathrm{~min}$ and right after shearing for $10 \%$ in the same order. It reaffirmed the combined effects of temperature, shearing, and concentration on the conformational changes. Compared to progress heating in our previous study of $5 \%$ solutions, the reflection time occurred at shearing for more than $25 \mathrm{~min}$. Because $11 \mathrm{~S}$ globulin dissociating into subunits or unfolding shortened the reflection time as the temperature increased above $80^{\circ} \mathrm{C}^{22)}$ However, for the $20 \%$ solution, the apparent viscosity remained constant. It may due to gel forming at high concentrations and temperatures and the low shearing force used in this study could not affect the gel system.
Changes of secondary structure of protein molecules caused by the thermal and shearing effects

The reasons for the sharp increase in the apparent viscosity as the temperature increased to $80^{\circ} \mathrm{C}$ and $90^{\circ} \mathrm{C}$ as shown in Fig. 6 may be due to the unfolding of soy $11 \mathrm{~S}$ globulin molecules. To elucidate the attributes of temperature and shear on the conformation, especial on the secondary structure of $11 \mathrm{~S}$ globulin, shearing at $384 \mathrm{sec}^{-1}$ and different temperatures was studied. Figure 7 shows the undeconvoluted (bottom), self-deconvoluted (middle), and second derivative of deconvoluted spectra of $11 \mathrm{~S}$ globulin obtained from shear at $25^{\circ} \mathrm{C}$ and shear rate of $384 \mathrm{sec}^{-1}$. The pairs wavenumber of Amide I and Amide II 
Table II. Changes of Infrared Bands of $11 \mathrm{~S}$ Globulin with Different Temperature and Shear at a Shear Rate of $384 \mathrm{sec}^{-1}$.

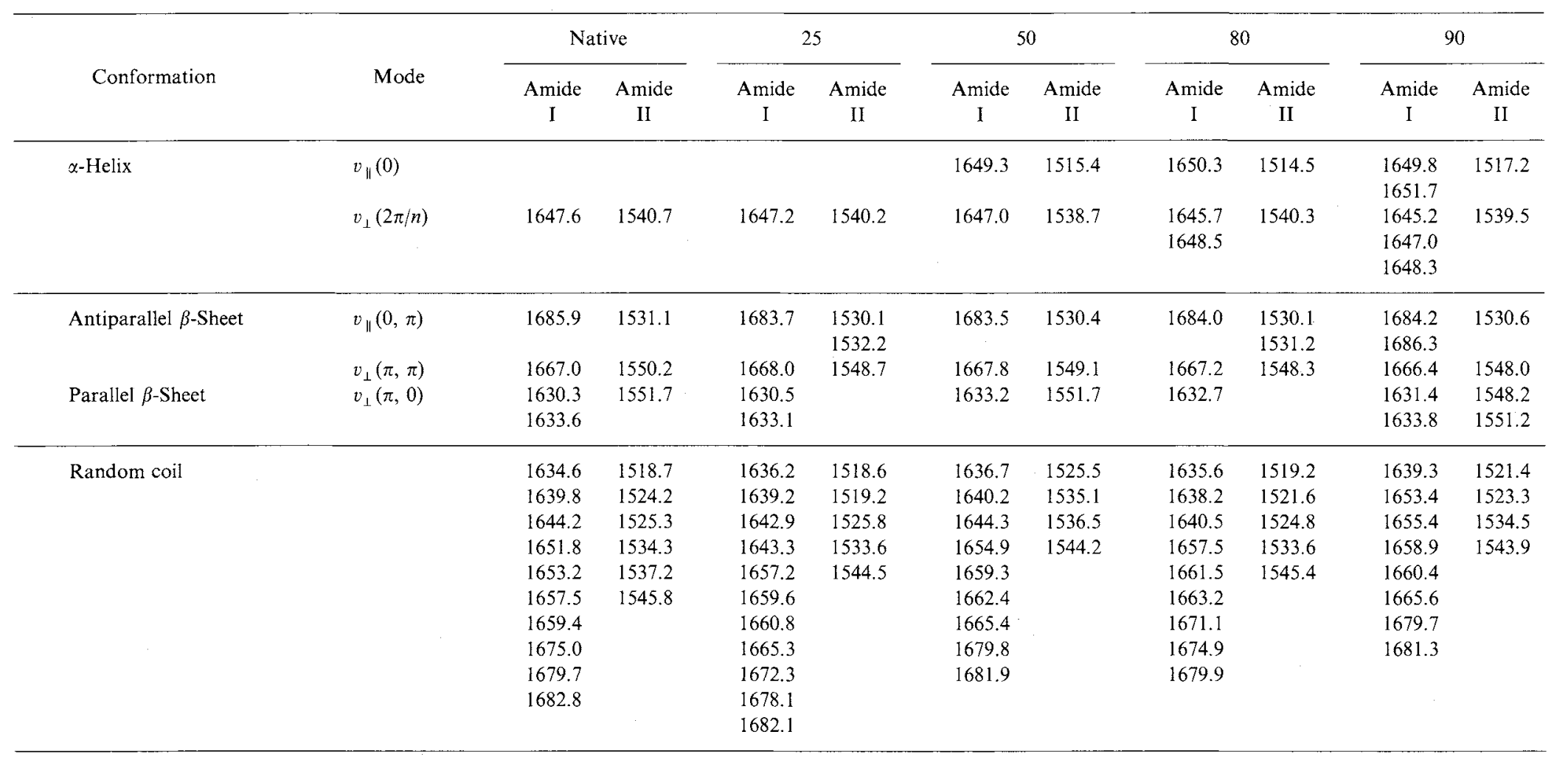

a The positions of wavenumber are verified by self-deconvolution spectra and second derivative of deconvolution spectra, which are printed out directly.from the computer program.

$b$ The selecting of the coupling wavenumber combination are referred to in Miyazawa and Blout (1961) in \pm 2 wavenumber.

c $25,50,80,90$ are shearing temperature $\left({ }^{\circ} \mathrm{C}\right)$ at a shear rate of $384 \mathrm{sec}^{-1}$. 
Table III. Changes of Secondary Structure of $11 \mathrm{~S}$ Globulin in Phosphate Buffer with Temperature at a Shear Rate OF $384 \mathrm{sec}^{-1}$

\begin{tabular}{lrrrrr}
\hline Temperature $\left({ }^{\circ} \mathrm{C}\right)$ & Native & 25 & 50 & 80 & 90 \\
\hline$\alpha$-Helix & 7.9 & 7.8 & 13.8 & 19.6 & 28.1 \\
$\beta$-Sheet & 28.3 & 26.6 & 27.6 & 25.4 & 29.4 \\
Order structure & 36.2 & 34.4 & 41.4 & 45.0 & 57.5 \\
Random coil & 63.8 & 65.6 & 58.6 & 55.0 & 42.5 \\
(unorder structure) & & & & &
\end{tabular}

used to calculate the quantitative changes of secondary structure were also labelled on the figure. The other spectra of shearing at $384 \mathrm{sec}^{-1}$ and heating at 50,80 , and $90^{\circ} \mathrm{C}$ were omitted, but pairs wavenumbers were all listed in Table II. The percentages were 7.8, 13.8, 19.6, and $28.1 \%$ of $\alpha$-helix; 26.6, 27.6, 25.4, and $29.4 \%$ of $\beta$-sheet and $65.6,58.6,55.0$, and $42.5 \%$ of random coil for heating at $25,50,80$, and $90^{\circ} \mathrm{C}$ respectively (Table III). It indicated that the higher the temperature that $11 \mathrm{~S}$ globulin was subjected to, the more $\alpha$-helix and the less random coil conformation of the molecules were formed. Especially, for the $90^{\circ} \mathrm{C}$ one, the percentage of $\alpha$-helix was $28.1 \%$ which is 3.5 times larger than the value of the native one, but the percentage of $\beta$-sheet changes was not significant. The increase of $\alpha$-helix should be at the expense of random coil conformation. The change of $\alpha$-helix was mainly the result of the vibration mode $v_{\|}(0)$ indicated by the stronger $1650,1516 \mathrm{~cm}^{-1}$ and 1647 , $1540 \mathrm{~cm}^{-1}$ peaks shown in the spectra at higher temperature. The data was consistency with the result of Damodaran ${ }^{23)}$ who reported $\mathrm{CD}$ spectrum of $11 \mathrm{~S}$ globulin supernatant from the gel preparation had a shoulder at $222 \mathrm{~nm}$ and a trough at $210 \mathrm{~nm}$, characteristic of $\alpha$-helix structure. It indicated that the heated unfolded $11 \mathrm{~S}$ globulin in $0.5 \mathrm{M} \mathrm{NaCl}$ solution partially refolds to an ordered structure containing more $\alpha$-helix than $\beta$-sheet conformation during the cooling phase. Suresh Chandra $^{24)}$ also reported that the $\alpha$-helix structure was increased by increasing temperature. Therefore, the apparent viscosity increasing drastically was the increase of the flow re- sistance that was induced by increasing axial ratio and/or molecular entanglements due to the more extended and stretched molecules result from the increase of $\alpha$-helix at the expense of random coil structure at $90^{\circ} \mathrm{C}$. Koshiyama et al. $^{25}$ reported the denaturation temperature of soy $11 \mathrm{~S}$ globulin in ionic strength $0.5, \mathrm{pH} 7.6$ buffer to be $89.5^{\circ} \mathrm{C}$, considering that the time to reach the limit of the viscometer was 8 and $16 \mathrm{~min}$ for 90 and 80 respectively. The difference mainly reflected the syneresis effect of shear/the thermal denature (unfolding, dissociation) and shear/the thermal unfolding respectively. Therefore, increasing the temperature to higher than $89.6^{\circ} \mathrm{C}$ will cause a more significantly effect on increasing the apparent viscosity, gelling formation capacity, axial ratio, etc. On the other hand, comparing the secondary structure changes of native $11 \mathrm{~S}$ globulin and that sheared at $25^{\circ} \mathrm{C}$ in Table III, the percentage of the random coil structure of the sheared one was larger than the native one, the result implying that the hydration and shearing at $25^{\circ} \mathrm{C}, 384 \mathrm{sec}^{-1}$ may cause a quaternary or tertiary structure change and result in some slight relative increase or decrease change in order and random coil structure changes.

Acknowledgment. Appreciative thanks for the financial support from the National Science Council, Republic of China. Project No. NSC78-0406-E019-05, and also thanks for the use of the Fourier transform infrared spectroscope in their instrument center.

\section{References}

1) M. A. Rao, J. Texture Stud., 8, 135 (1977).

2) J. E. Kinsella, J. Am. Oil Chemist's Soc., 56, 242 (1979).

3) C. K. Rha, Food Technol., 32, 77 (1978).

4) R. E. Harrington, in "Food Analysis Principies and Technique," Vol 2, ed. by D. W. Gruenwedel and $\mathbf{J}$. R. Whitaker, Marcel Dekker, New York, 1984, pp. 95-174.

5) A.-M. Hermansson, J. Texture Stud., 5, 425 (1975).

6) T. Furukawa and S. Ohka, Agric. Biol. Chem., 47, 745 (1983).

7) S. E. Fleming, F. W. Sosulski, A. Kilara and E. S. Humbert, J. Food Sci., 39, 188 (1974).

8) J. I. Umeya, F. Yamauchi and K. Shibasaki, Agric. 
Biol. Chem., 44, 1321 (1980).

9) S. J. Circle, E. W. Meyer and R. Whitney, Cereal Chem., 41, 151 (1964).

10) A.-M. Hermansson and C. Akesson, J. Food Sci., 40, 595 (1975).

11) C. H. Lee and C. K. Rha, in "Food Texture and Rheology," ed. by P. Sherman, Academic Press, London, 1979, pp. 245-263.

12) N. Catsimpoolas and E. W. Meyer, Agric. Chem., 47, 559 (1970).

13) K. Ishino and S. Okamoto, Cereal Chem., 52, 9 (1975).

14) K. Ishino and S. Kudo, Agric. Biol. Chem., 43, 1029 (1979).

15) Y. C. Ker, R. H. Chen and C. S. Wu, Agric. Biol. Chem., submitted.

16) J. K. Kauppinen, D. J. Moffatt, H. H. Mantsch and D. G. Gameron, Appl. Spectros., 35, 271 (1981).

17) S. D. Holdsworth, J. Texture Stud., 2, 393 (1971).
18) P. Pradipasena and C. K. Rha, J. Texture Stud., 8, 311 (1977).

19) C. F. Shoemaker and P. I. Figoni, Food Technol., 38, 110 (1984).

20) J. L. Shen, J. Agric. Food Chem., 24, 786 (1976).

21) S. S. Ross-Murphy, in "Biophysical Methods in Food Research," Vol 5, ed. by H. W.-S. Chan, Critical Reports on Applied Chem., London, 1984, pp. 138-199.

22) B. German, S. Damodaran and J. E. Kinsella, $J$. Agric. Food Chem., 30, 807 (1982).

23) S. Damodaran, J. Agric. Food Chem., 36, 262 (1988).

24) B. R. Suresh Chandra, A. G. Appu Rao and M. S. Narasinga, J. Agric. Food Chem., 32, 1402 (1984).

25) I. Koshiyama, M. Hamano, D. Fukushima, Food Chem., 6, 309 (1981).

26) T. Miyazawa and E. R. Blout, J. Am. Chem. Soc., 83, 712 (1961). 